\title{
Effect of genetic deletion and pharmacological antagonism of P2X7 receptors in a mouse animal model of migraine
}

\author{
Flóra Gölöncsér ${ }^{1,2}$ and Beáta Sperlágh ${ }^{1 *}$
}

\begin{abstract}
Background: Purine receptors participate in peripheral and central sensitization and are associated with migraine headache. We investigated the role of P2X7 receptor (P2X7) in a nitroglycerin (NTG)-induced mouse model of migraine.

Methods: Intraperitoneal NTG injection $(15 \mathrm{mg} / \mathrm{kg}$ ) triggered thermal hyperalgesia in the hindpaws of wild-type C57BL/6J mice, followed by the induction of c-fos in upper cervical spinal cord and trigeminal nucleus caudalis. The effect of genetic deletion of P2X7 and the selective P2X7 antagonist Brilliant Blue G (BBG) were examined on hyperalgesia and c-fos induction.

Results: NTG decreased the paw withdrawal threshold in both wild-type and P2X7 knockout mice. Nevertheless, subacute BBG treatment (50 mg/kg/day i.p.) completely prevented the effect of NTG in wild-type, but not in knockout mice. Whereas P2X7 deficiency differentially affected the expression of $\mathrm{c}$-fos, the average number of fos-immuno-reactive neurons in trigeminal nucleus caudalis, but not in upper cervical spinal cord was lower in BBG-treated wild-type mice after NTG treatment.

Conclusions: Our results show that P2X7 receptors might participate in the pathogenesis of migraine, although upregulation of other P2X receptors probably compensate for the loss of its action in knockout mice. The data also suggest the therapeutic potential of P2X7 antagonists for the treatment of migraine.
\end{abstract}

Keywords: P2X7 receptor; Brilliant blue G; nitroglycerin; mouse model; migraine

\section{Background}

Headache is a common pain disorder affecting an estimated $11 \%$ of the general population [1] and the global prevalence of chronic migraine is $0.5-1 \%$ [2]. Despite increasing knowledge regarding migraine pathophysiology, drug therapies used for prevention and treatment of symptoms remain unsatisfactory for many patients. Therefore, it is necessary to continue development of new drugs and to identify promising new cellular or molecular targets [3].

Migraine is a complex brain disorder, characterized by predominantly unilateral pulsating head pain, which can be aggravated by routine physical activity and accompanied by

\footnotetext{
* Correspondence: sperlagh@koki.hu

${ }^{1}$ Laboratory of Molecular Pharmacology, Institute of Experimental Medicine, Hungarian Academy of Sciences, H-1083, Budapest, Szigony u. 43, Hungary Full list of author information is available at the end of the article
}

neurological symptoms including nausea, vomiting, hypersensitivity to light, sound and smell and visual disturbances as well as cognitive, emotional and motor disturbances. Before and during migraine attacks, headache is accompanied by increased skin sensitivity to touch, heat and cold (cutaneous allodynia) $[4,5]$ and normally innocuous stimuli can be unpleasant and painful.

Among the variety of experimental models of migraine attacks, nitroglycerin (NTG) is amongst the most widely used and accepted approaches, in both animals and human [6]. Several reports show that the clinical use of NTG induces delayed spontaneous headache in migraine patients [7-9] coupled with accompanying symptoms. NTG-derived nitric oxide (NO) activates brainstem regions and neuronal populations which are involved in environmentally triggered migraine attacks [10] and prophylactic agents can block NTG-induced headaches 
in human $[11,12]$. Furthermore, NTG can provoke cutaneous allodynia in migraine sufferers [13] including in non-cranial regions $[4,5]$. Previous studies showed that systemic administration of NTG induces hyperalgesia of the hindpaws, which is inhibited by the antimigraine drug sumatriptan in mice [14]. These observations validate extrafacial thermal and mechanical hyperalgesia as a potential behavioural correlate of migraine in mice subjected to NTG. NTG administration also activates neuronal populations in selected areas of the brain that are primarily involved in the transmission of cephalic pain, including the trigeminal nucleus caudalis (TNC) in rodents [14-16]. Chemical activation of the C-fibers of the trigeminal nerve - leading to transmission of nociceptive information into the brainstem - induces c-fos expression within specific areas of the TNC. This is inhibited by anti-migraine therapeutics, such as olcegepant [17]. These findings indicate that those drugs, which influence c-fos expression in the TNC might have relevance in the mediation of potential anti-migraine effects.

The purinergic signalling system consists of enzymes, transporters and receptors responsible for the action of extracellular nucleotides, particularly ATP and adenosine. The actions of extracellular nucleotides are mediated by various subtypes of ionotropic P2X (P2X1-7) and metabotropic P2Y (P2Y $, \mathrm{P}_{2}, \mathrm{P}_{4}, \mathrm{Y}_{4} \mathrm{Y}_{6}, \mathrm{P}_{11}$, $\left.\mathrm{P}_{12} \mathrm{Y}_{12}, \mathrm{P}_{2} \mathrm{Y}_{13}, \mathrm{P} \mathrm{Y}_{14}\right)$ receptors. The potential involvement of the purinergic signalling system in the pathophysiology of migraine was recognized more than thirty years ago [18]. Since then, the role of different subtypes of $\mathrm{P} 2$ receptors has been elucidated in different pain modalities, amongst which, the role of P2X3, and various P2Y receptor subtypes have already been proposed and examined in cellular and animal models of migraine [19-24]. ATP is released during spreading depression (SD), a phenomenon thought to underlie aura both in vitro [25] and in vivo [26], which raises the possibility that endogenous purines could act as potential triggers or mediators of migraine.

P2X7 receptors (P2X7) belong to the P2X family of receptors, which are ligand-gated, non-selective cation channels. P2X7 is widely expressed in various cell types involved in pain transmission, including neurons, microglia, satellite glial cells, astrocytes in dorsal root ganglia, trigeminal ganglia and the dorsal horn of the spinal cord e.g. [27-29]. Several studies have demonstrated that P2X7 is involved in the modulation of pathological nociception. P2X7 knockout mice showed a lack of hypersensitivity to mechanical and thermal stimuli [30,31] and P2X7-specific antagonists have consistently been shown to be protective in animal models of inflammatory [32-34] and neuropathic pain [33,35]. Moreover, recent studies have highlighted that variation within the gene encoding P2X7 can affect chronic pain sensitivity in both mouse and human [36]. The role of P2X7, however, has not examined in any whole animal model of migraine.

The objective of this study, therefore, was to examine how genetic deletion and pharmacological blockade of P2X7 affects NTG-induced thermal hypersensitivity and c-fos induction in migraine related CNS areas in mice. We report here that although genetic deletion of P2X7 (P2X7-/-) results in non-significant changes in the nociceptive threshold after NTG treatment, the selective P2X7 antagonist, BBG completely prevents the effect of NTG in wild-type, but not in P2X7-/- mice and also alleviates NTG-induced c-fos expression.

\section{Methods \\ Animals}

All experiments were conducted in accordance with the principles and procedures outlined in Guide for the Care and Use of Laboratory Animals of the National Institute of Health. The local Animal Care Committee of the Board of the Institute of Experimental Medicine, Hungarian Academy of Sciences approved all experimental procedures (Permission No: 22.1/3671/003/2008). This study used drug and test naïve, 3-month old (approx. $30 \mathrm{~g}$ ), male wild-type $(\mathrm{P} 2 \mathrm{X} 7+/+)$, and P2X7 knockout mice (P2X7-/-). Breeding pairs of P2X7-/- homozygote knockout mice (C57BL/6J based) were originally supplied by Christopher Gabel (Pfizer Inc., Groton, CT, USA). The animals contained the DNA constructs P2X7-F1 (5_-CGGCGTGCGTTTTGA CATCCT-3_) and P2X7-R2 (5_-AGGGCCCTGCGGTT CTC-3_), which have previously been shown to produce genetic deletion of P2X7 [37]. Homozygous knockout mice (P2X7-/-) and P2X7+/+ (C57BL/6) littermates were bred in the local animal house (IEM HAS, SPF Unit). The genotype of the mice was tested by PCR analysis as previously described [37]. Mice were housed under standard laboratory conditions with food and water available ad libitum, in a 12 -h light-dark cycle at a temperature of $21-23^{\circ} \mathrm{C}$. All efforts were made to minimize animal suffering and reduce the number of animals used. Experiments were carried out between 9:00 and 14:00 in the same room in which the animals were housed, whilst perfusion took place in a different room.

\section{Drugs and treatments}

A modified version of NTG model described by Bates et al. [14] was used. Animals received intraperitoneal (i.p.) injections of $15 \mathrm{mg} / \mathrm{kg}$ NTG (Nitro POHL ${ }^{\circ}, \mathrm{G}$. Pohl-Boskamp GmbH \& Co. KG, Hohenlockstedt, Germany) or vehicle (49 $\mathrm{mg}$ glucose monohydrate $/ \mathrm{ml}$ ) after the measurement of the baseline thermal nociceptive threshold. The dose of NTG was chosen based on literature data [14] and preliminary tests. Sumatriptan succinate (Sigma-Aldrich, Hungary), dissolved in saline was used to validate our experiments: each animal was given i.p. 
sumatriptan at the dose of $600 \mu \mathrm{g} / \mathrm{kg}$ [14] or saline 5 minutes after NTG administration. The P2X7 antagonist, Brilliant Blue G (BBG, Sigma-Aldrich, Hungary) or its vehicle $(0.9 \%$ saline), were applied in an identical way, or using two different prophylactic application protocols: acutely $(50 \mathrm{mg} / \mathrm{kg})$, it was applied i.p. 30 minutes prior to NTG treatment and after the measurement of the baseline thermal nociceptive threshold on the day of testing. In subacute treatment, mice were treated for 5 consecutive days with the daily doses of BBG (50 mg/kg i.p.) or saline and $30 \mathrm{~min}$ after the last injection were subjected to NTG. Selection of dose was based on previous studies [38,39]. All drug solutions were freshly prepared on the day of use.

\section{Increased temperature hot plate test (ITHT)}

Mice were randomly assigned to experimental groups of 10-13 and housed 5 per cage for 1 week prior to experimentation. An Excel protocol was used to randomize the animals, and codes unblinded only after the experiment. Responsiveness of mice to nociceptive stimulation was measured by an increasing-temperature hot plate system (IITC Life Science, Woodland Hills, CA, USA). On the day of testing, animals were habituated to the testing apparatus for $10 \mathrm{~min}$ prior to determination of baseline nociceptive threshold. The animals were placed on an electrically heated metal plate that was kept at a constant temperature of $30^{\circ} \mathrm{C}$ (starting temperature). After the habituation period the plate was heated from the starting temperature with a constant rate of $6^{\circ} \mathrm{C} /$ min, until the animals showed nocifensive behaviour (frequent pawlifting and/or pawlicking in both front and back paws, jumping).

Heating was then instantly stopped, the animal removed from the apparatus and the plate rapidly cooled. The temperature at which the animal showed the first sign of nocifensive behaviour was taken as the paw withdrawal threshold (PWT), expressed in ${ }^{\circ} \mathrm{C}$. Approximately 1 hour later, the measurement was repeated and the average of two values was taken as the baseline thermal nociceptive threshold. After the second measurement, the animals received treatment with drugs as described above and one and two hours after nitroglycerin administration, post-drug nociceptive threshold was measured.

\section{Immunohistochemistry (IHC)}

Among animals undergoing behavioural testing, 5-8 mice/ experimental group were selected by randomization prior to experimentation and were assigned to be the subject of subsequent perfusion and immunohistochemistry. Two hours following i.p. injection of NTG $(15 \mathrm{mg} / \mathrm{kg})$ or vehicle, mice were anaesthetized with ketamine and xylazine (i.p.) and perfused with fixative solution (containing $0.5 \%$ borax $\left(\mathrm{Na}_{2} \mathrm{~B}_{4} \mathrm{O}_{7} 10 \quad \mathrm{H}_{2} \mathrm{O}\right)$ and $5 \%$ paraformaldehyde). Whole brain and spinal cord were removed and fixed for $3 \mathrm{~h}$ in $5 \%$ paraformaldehyde, and transferred to $30 \%$ sucrose in fixative solution for 20-24 h. Samples were then frozen and transverse sections cut at $30 \mu \mathrm{m}$. Every fourth section was collected for free-floating IHC. After blocking the endogenous peroxidase activity with $0.3 \%$ hydrogen-peroxide, sections were incubated in $0.3 \%$ Triton X-100 and $2 \%$ normal goat serum for $1 \mathrm{~h}$, followed by incubation with anti-fos (raised in rabbit, 1:10000, $72 \mathrm{~h}$ at $4^{\circ} \mathrm{C}$, sc-52, Santa Cruz Biotechnology). Sections were then washed in PBS before incubation for $1 \mathrm{~h}$ in biotinylated goat anti-rabbit secondary antibody, and incubated with avidin-biotin-complex (Vectastain - ABC kit PK-6100 Elite, 1 h). Peroxidase activity was detected with 3,3'-diaminobenzidine (Sigma-Aldrich, Hungary). Mounted and coverslipped sections were microphotographed and fos-immuno-reactive nuclei were counted within both sides of the cervical spinal cord and the TNC using ImageJ software. We counted 30 hemi-sections from each hemisphere per animal (TNC) and 10 hemi-sections from each hemisphere per animal (cervical spinal cord) and calculated the average number of c-fos positive nuclei in each section.

\section{Statistics}

All data were expressed as means \pm SEM of $n$ observations. For statistical comparison of thermal sensitivity after treatments in $\mathrm{P} 2 \mathrm{X} 7+/+$ and $\mathrm{P} 2 \mathrm{X} 7-/-$ mice, a repeated measures analysis of variance ANOVA was used to identify genotype, treatment and time effects. The number of $\mathrm{c}$-fos positive nuclei in spinal cord and TNC was compared by two-way ANOVA. Where the variance was not homogeneous based on a significant Levene's test, we used the Kruskal-Wallis nonparametric test. The Fischer LSD test was used for post hoc comparison. For pairwise comparisons, the Student $t$ test was used. All tests were performed by the STATISTICA software package (StatSoft, Tulsa, OK, USA).

\section{Results}

\section{Effect of genetic deletion of P2X7 on NTG-induced ther-} mal hypersensitivity

The baseline nociceptive threshold in wild-type (P2X7+/+) mice was $45.95 \pm 0.14^{\circ} \mathrm{C} \quad(n=68)$. NTG significantly and time-dependently reduced PWT, when compared with vehicle treatment (at $1 \mathrm{~h}: 100.70 \pm 1.25 \%, \mathrm{n}=12$; and $93.56 \pm 0.95 \%, \mathrm{n}=13 ; 2 \mathrm{~h}: 100.92 \pm 1.13 \%, \mathrm{n}=12$; and $95.06 \pm 1.13 \%, \mathrm{n}=13$, in vehicle and NTG-treated mice, respectively, $*$ $* 0.0001$; Figure 1 ).

For the validation of the model, the antimigraine drug sumatriptan $(600 \mu \mathrm{g} / \mathrm{kg}$ i.p.) was chosen as it is known to reverse NTG-induced thermal hypersensitivity in mice [14]. In $\mathrm{P} 2 \mathrm{X} 7+/+$ mice, treated with sumatriptan 5 min after NTG, PWT was higher than in mice treated with an identical volume of saline (at $1 \mathrm{~h}$ : $98.74 \pm 1.66 \%$, $\mathrm{n}=10 ; \quad 93.43 \pm 1.80 \%, \quad \mathrm{n}=10, \quad \mathrm{p}=0.0375$ in $\mathrm{NTG}+$ 


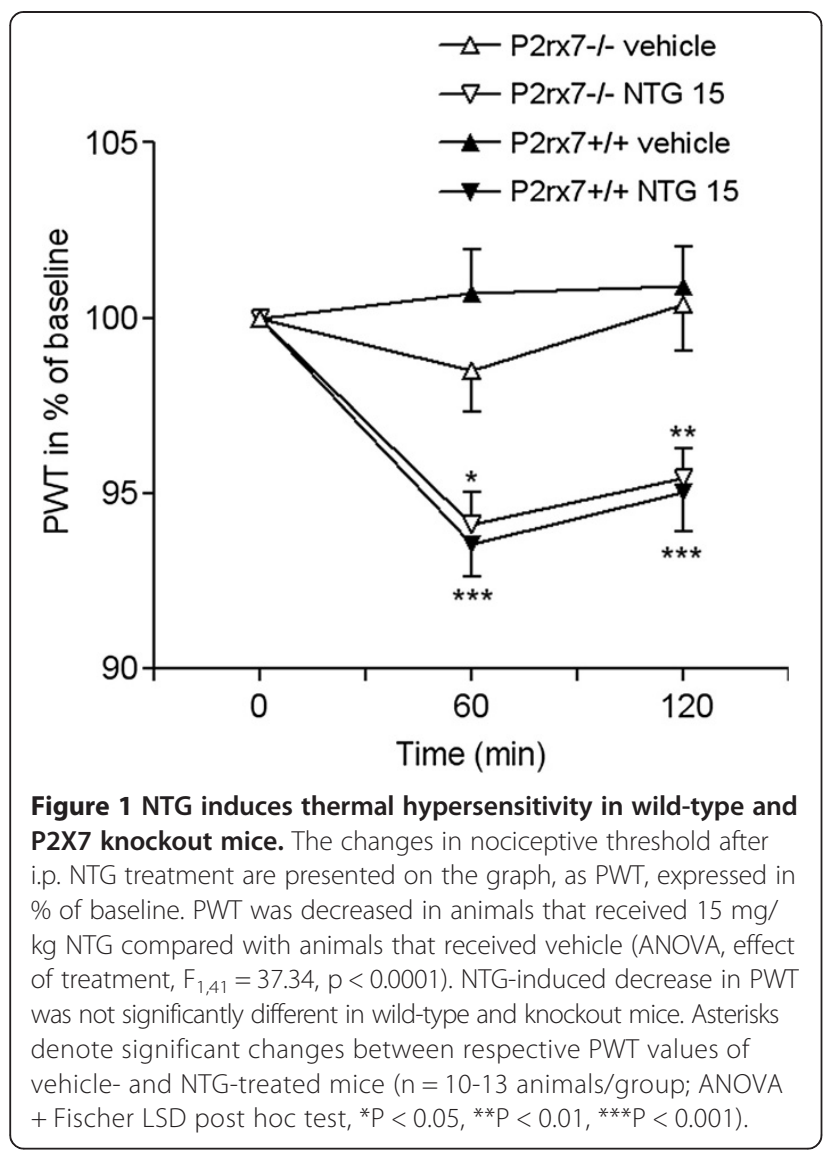

sumatriptan and NTG + saline treated mice, respectively, Figure 2).

In P2X7-/- mice, the baseline PWT values were not significantly different from $\mathrm{P} 2 \mathrm{X} 7+/+$ mice $\left(45.47 \pm 0.23^{\circ} \mathrm{C}, \mathrm{n}=\right.$ 20; $\mathrm{p}=0.1015$; Student's $t$-test). Likewise, the NTG-induced decrease in PWT was not significantly different in wildtype and knockout mice (ANOVA genotype $\times$ treatment effect $\mathrm{F}_{1,41}=1.00, \mathrm{p}=0.3243$; Figure 1 ).

\section{P2X7R antagonist prevents NTG-induced thermal hypersensitivity}

Next, we asked whether systemic administration of a specific P2X7 antagonist, BBG, can alleviate NTG-induced thermal allodynia in mice. When administered 5 min after the NTG injection, BBG had no effect on thermal hypersensitivity in wild-type mice (Figure 2). However, when BBG was given as a prophylactic agent, 30 min before administration of NTG, it was already effective upon single application (Figure 3), and it completely prevented the effect of NTG after 5-days treatment in wild-type mice. In contrast, an identical BBG administration was ineffective in NTG-treated P2X7 knockout mice (ANOVA genotype $\times$ treatment effect $F_{1,45}=6.36, p=0.0153$; Figure 4). The 5day treatment with BBG did not change the baseline thermal sensitivity of either genotype (P2X7+/+: $44.38 \pm 0.27^{\circ} \mathrm{C}$,

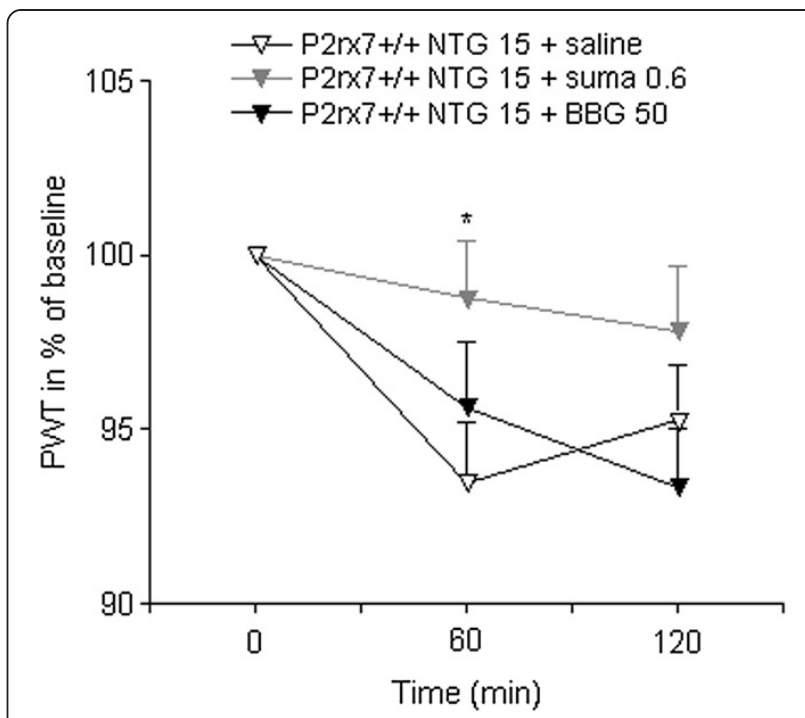

Figure 2 The effect of symptomatic treatment with sumatriptan and P2X7-selective antagonist BBG. Wild-type mice were treated with $600 \mu \mathrm{g} / \mathrm{kg}$ sumatriptan $/ 50 \mathrm{mg} / \mathrm{kg}$ BBG i.p. or an identical volume of saline 5 min after NTG treatment. PWT is expressed in \% of baseline. Asterisk indicate significant changes between respective PWT values of saline- and sumatriptan-treated mice $(n=10$ animals/group; ANOVA + Fischer LSD post hoc test, $\left.{ }^{*} P<0.05\right)$.

$\mathrm{n}=16 ; \mathrm{p}=0.9929, \quad \mathrm{P} 2 \mathrm{X} 7-/-: 44.86 \pm 0.39^{\circ} \mathrm{C}, \mathrm{n}=17 ; \mathrm{p}=$ 0.167 vs. baseline PWT, Student's $t$-test).

\section{NTG induced c-fos expression in trigeminal nucleus and spinal cord}

As an index of activation of the nociceptive fibres implicated in migraine, changes in the average number of cfos-immuno-reactive nuclei in the upper cervical dorsal horn and TNC $2 \mathrm{~h}$ after $15 \mathrm{mg} / \mathrm{kg}$ NTG injection were quantified. In line with previous findings [14,15], NTG profoundly increased c-fos expression in both areas, when compared to vehicle-treated animals (Figure 5). In knockout mice, NTG caused the same elevation in c-fos expression in TNC, compared with vehicle, whereas the c-fos level was slightly lower in the spinal cord (Figure 5A). Two-way ANOVA of the c-fos data in the C1-2 and TNC indicated a significant effect of NTG treatment, without an interaction effect of genotype with NTG (C1-2: $\mathrm{F}_{1,19}=13.92, \mathrm{p}=0.0014$; TNC: $\mathrm{F}_{1,19}=48.14$, $\mathrm{p}<0.0001)$. Due to unequal variance, a Kruskal-Wallis nonparametric test was used for comparison of groups. It indicated that NTG significantly increased c-fos levels in the C1-2 of wild-type (WT: $\mathrm{p}=0.0374$; KO: $\mathrm{p}=$ 0.0679 ) and TNC of wild-type and knockout mice, respectively (WT: $\mathrm{p}=0.0039 ; \mathrm{KO}: \mathrm{p}=0.0062$ ). Further, post hoc testing by Fischer LSD test revealed that NTG significantly increased fos level in the C1-2 and TNC of wild-type and knockout mice (Figure 5A). 


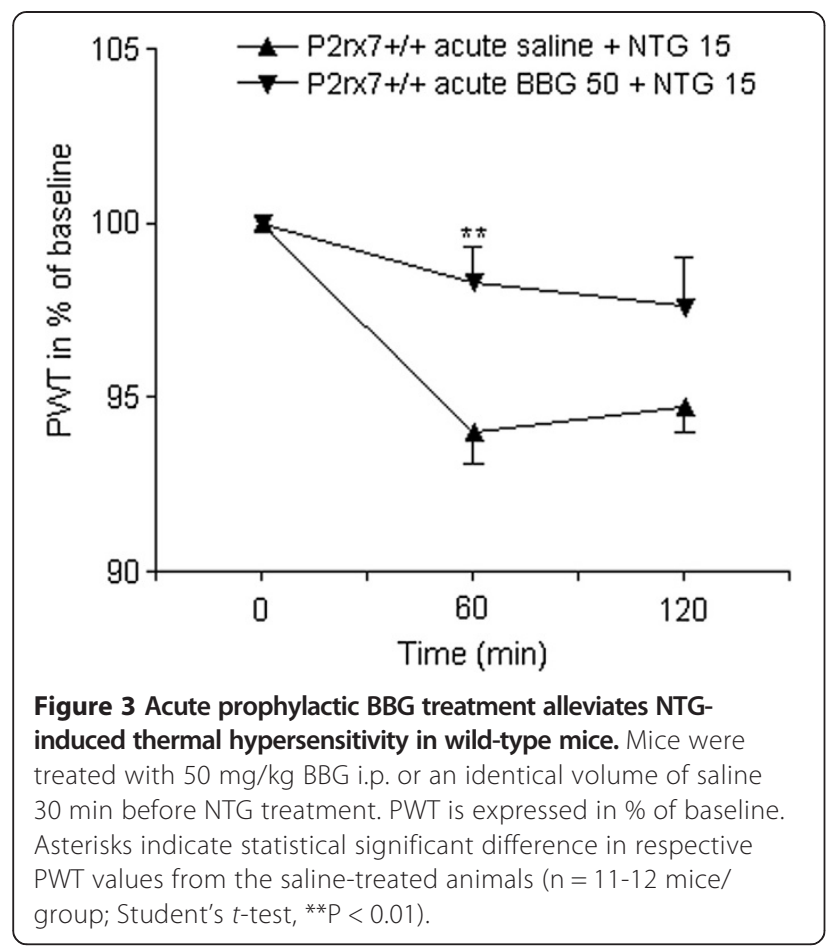

5-day treatment with the P2X7 antagonist BBG (50 mg/ $\mathrm{kg}$ i.p.) elicited a reduction in the level of c-fos after NTG treatment in TNC in wild-type mice, which was significant, when compared to an identical saline treatment (Figure 5F, $\mathrm{G}$ and $\mathrm{H}, 106.63 \pm 3.99, \mathrm{n}=8 ; 132.68, \mathrm{n}=6 ; \mathrm{p}=0.0022$, in $\mathrm{BBG}+\mathrm{NTG}$ and saline + NTG treated mice, Student $t$ test, respectively).

\section{Discussion}

The principal new finding of the present study is that antagonism of P2X7 by treatment with the specific P2X7 antagonist BBG leads to the alleviation of NTG-induced thermal hypersensitivity in mice. Moreover, as BBG treatment was ineffective in mice lacking P2X7, it is reasonable to assume that its effect is mediated by P2X7. The NTG-evoked c-fos expression in the TNC was also attenuated after subacute BBG treatment, which implicates a role for the TNC in mediating the effect of BBG on NTG-induced thermal hypersensitivity. All these findings implicate the therapeutic potential of P2X7 blockade in migraine.

We have used the NTG-induced migraine model described recently by Bates et al. [14] and reproduced findings showing that i.p. injection of NTG elicits thermal hypersensitivity in a time-dependent manner. We have also replicated the finding that NTG-induced thermal hypersensitivity is attenuated by the antimigraine drug, sumatriptan, and is followed by the expression of c-fos in the trigeminal nucleus of the brainstem and upper spinal cord [14]. Although the dose of NTG necessary to

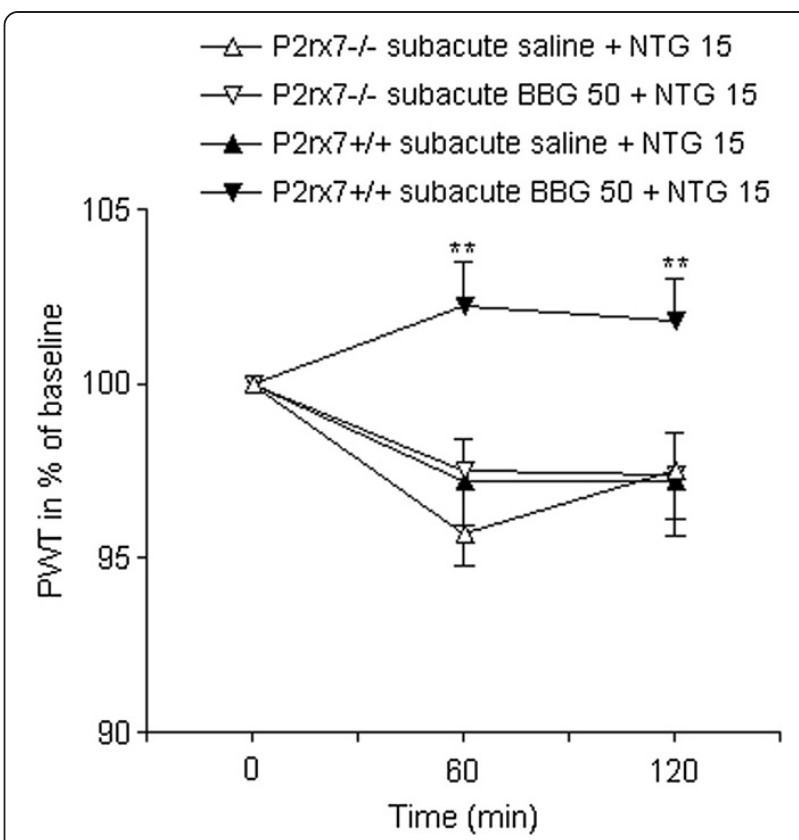

Figure 4 Subacute treatment with BBG reverses NTG-induced thermal hypersensitivity in wild-type mice, but not in P2X7 knockout mice. Mice were treated for 5 consecutive days with daily doses BBG (50 mg/kg i.p.) or saline and on the fifth day NTG was given 30 min after BBG or saline and then submitted to the ITHT. PWT is expressed in \% of baseline. Asterisks indicate significant changes between respective PWT values of saline- and BBG-treated mice $(n=9-16$ animals/group; ANOVA + Fischer LSD post hoc test, $\left.{ }^{*} \mathrm{P}<0.01\right)$.

induce a significant drop in PWT (15 mg/kg), was somewhat higher than used by Bates et al. [14], this may be explained by differences in the source of NTG, or by the variation in the tests used to evaluate thermal nociception (Hargreaves test vs. ITHT). The interspecies variations in NTG sensitivity are well known and may be due to differences in the efficiency of hepatic bioactivation of NTG into the pharmacologically active NO [40]. This might also account for slight differences between NTG responsiveness observed in different rodent species [14-16].

Following the study of Almási et al. [41], we have used the ITHT to measure thermal nociceptive threshold, in our experiments instead of the widely used latency measurements. As reported in this study, ITHT is a more accurate assay of thermal hyperalgesia although the changes in response to traditional analgesic drugs, such as diclofenac and paracetamol, are not more than $2.0-2.5^{\circ} \mathrm{C}$ in this test. Accordingly, similar changes were measured, in response to the antimigraine drug sumatriptan, indicating that the assay system reflects changes specific to antimigraine therapy.

Interestingly, no differences in NTG-induced thermal hypersensitivity in P2X7-/- mice were detected, when compared to their wild-type counterparts. The most likely explanation for this negative finding is the 

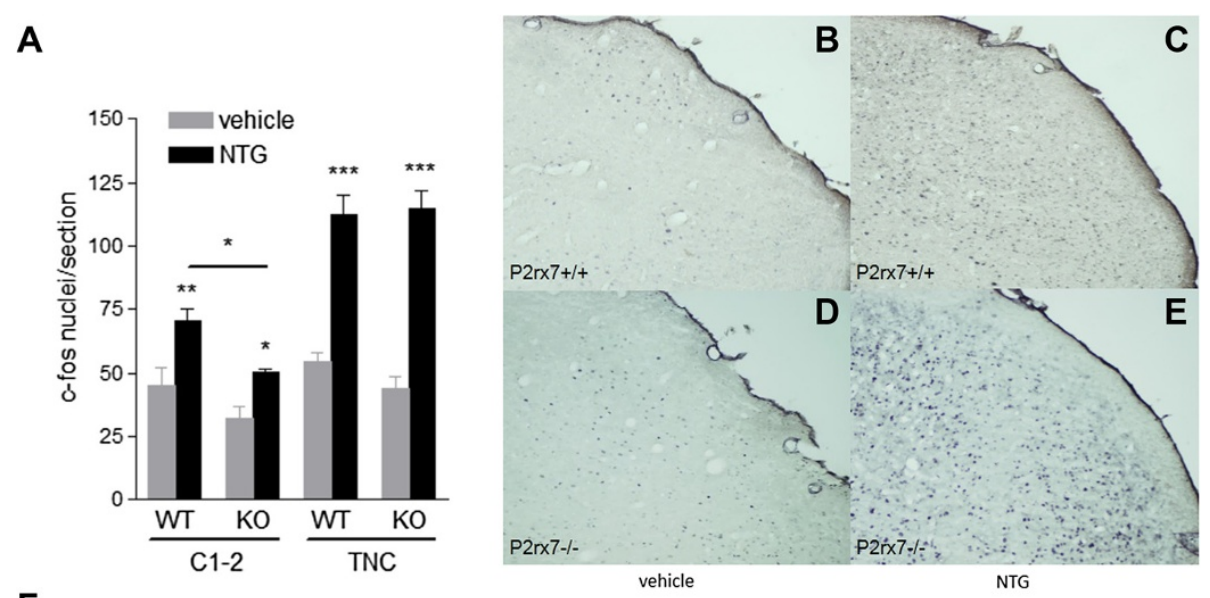

$\mathbf{F}$
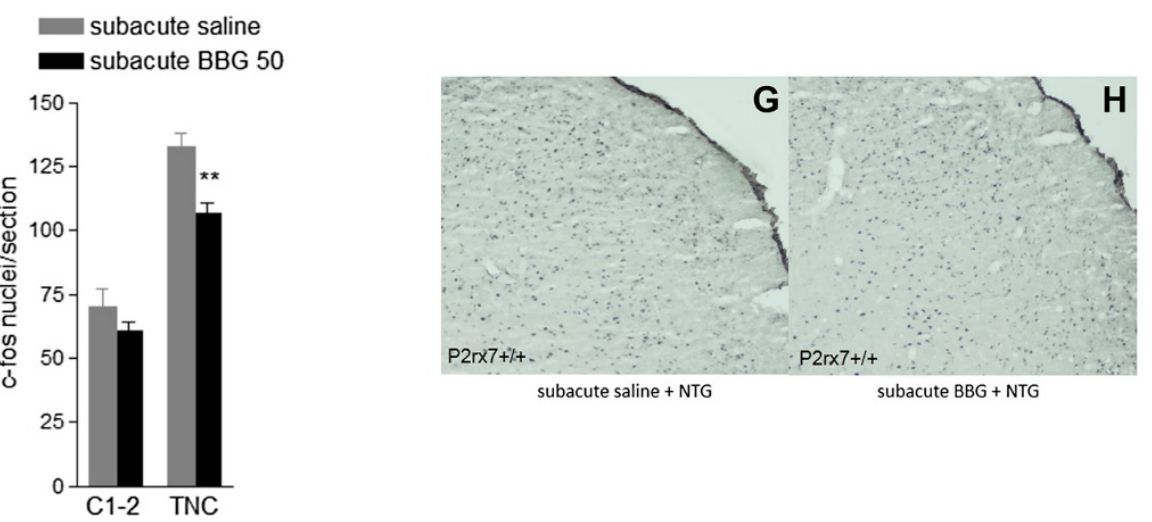

Figure 5 NTG-induced fos expression in wild-type and P2X7 knockout mice. A. Quantification of fos-immuno-reactive nuclei in upper cervical spinal cord (C1-2) and TNC $2 \mathrm{~h}$ after $15 \mathrm{mg} / \mathrm{kg}$ NTG or vehicle. We counted 10 hemi-sections from each hemisphere for upper cervical spinal cord, and 30 hemi-sections from each hemisphere that included TNC from both sides ( $n=5-6$ animal/group; Kruskal-Wallis nonparametric ANOVA followed by Fischer LSD post hoc test, ${ }^{*} \mathrm{P}<0.05,{ }^{*} \mathrm{P}<0.01$, $\left.{ }^{* *} \mathrm{P}<0.001\right)$. F. The subacute BBG treatment $(50 \mathrm{mg} / \mathrm{kg}$ i.p.) decreased the number of c-fos immuno-reactive cells in TNC, but not in C1-2 in wild-type mice ( $n=6-8$ animal/group; Student $t$ test **P $<0.01)$. B,C,D,E,G,H Representative examples of c-fos immuno-reactivity in the TNC $2 \mathrm{~h}$ after i.p. administration of vehicle or $15 \mathrm{mg} / \mathrm{kg} \mathrm{NTG}$ in P2X7+/+ (B,C) and P2X7-/- mice (D, E), and after subacute BBG (50 mg/kg i.p.) or saline $+15 \mathrm{mg} / \mathrm{kg} \mathrm{NTG}$ treatment in P2X7 +/+ mice (G,H), shown here with a 10X objective.

potential developmental upregulation of non-P2X7 $\mathrm{P} 2 \mathrm{X}$ receptors in $\mathrm{P} 2 \mathrm{X} 7-/-$ mice, such as $\mathrm{P} 2 \mathrm{X} 3$ or $\mathrm{P} 2 \mathrm{X} 4$. In fact we have previously shown the upregulation of P2X4 mRNA in mice deficient of P2X7 [42].

When applied prophylactically, however, both acute and subacute BBG treatment was effective in the alleviation of NTG-induced thermal hypersensitivity in the P2X7+/+mice. BBG is known to permeate the blood brain barrier, and is thought to be specific to P2X7 in the applied dose. Although in vitro experiments revealed that BBG can inhibit $\mathrm{Na}^{+}$channels in micromolar concentrations [43], in in vivo studies using a similar dose (45.5 mg/kg), BBG has not reached higher concentrations in the brain than $200 \mathrm{nM}$ [44], which is selective for P2X7 [45]. The finding that its effect was completely lost in P2X7-/- mice also refutes the possibility of other target for BBG than P2X7 in these experiments.

Although further experiments are necessary to clarify this issue, there are several potential mechanisms, whereby endogenous P2X7 could participate in the sensitization of the trigeminovascular system. ATP is a well-known dangersignal, which is released in response to cell injury, inflammation, mechanical and metabolic distress, and is per se an algogenic substance $[46,47]$. P2X7 is a ligand-gated cation channel with high $\mathrm{Ca}^{2+}$ permeability, which participates in pain transmission in various ways. In the dorsal root ganglia P2X7 is expressed on satellite glia and potentiate P2X3 receptor mediated signalling by the release of pro-inflammatory cytokine TNF- $\alpha$ [48]. An analogous mechanism might also play a part in migraine, as satellite glia of the trigeminal ganglion express P2X7 [49] and $\mathrm{P} 2 \mathrm{X} 3$ receptors participate in craniofacial pain by interacting with NGF, substance P and CGRP $[20,22]$. P2X3 receptors also display an enhanced activity in a genetic animal model of migraine [50]. Alternatively, P2X7 antagonists may act more centrally, at the level of the upper cervical spinal cord or trigeminal nucleus. P2X7 modulates the afferent nociceptive information 
processing within the dorsal horn of the spinal cord [35] and its activation participates in the central sensitization underlying hindpaw hyperalgesia [34]. Because moderate-high density of P2X7 receptor binding sites were found in the grey matter of the trigeminal nucleus [28] the detected alleviation of NTG induced c-fos expression in response to BBG indicates that the $\mathrm{TNC}$ is a potential target area for the action of $\mathrm{P} 2 \mathrm{X} 7$ receptor antagonists. The activation of $\mathrm{P} 2 \mathrm{X} 7$ releases excitatory amino acids in this area [27], the blockade of which might underlie the action of BBG.

Furthermore, P2X7 is also expressed in other areas of the brain [28]; therefore, a supraspinal action through diencephalic, brainstem or cortical regions cannot be excluded [51]. Finally, P2X7 is expressed on circulating and locally recruited immune cells and the best characterized action of $\mathrm{P} 2 \mathrm{X} 7$ activation is its role in the posttranslational processing of pro-inflammatory cytokines, IL- $1 \beta$ and TNF- $\alpha[30,37,52]$, which are also known algogenic substances.

\section{Conclusion}

The data present here indicates that inhibition of P2X7 might be a potential target for the prophylaxis of migraine. Moreover, because BBG is a closed structural analogue of a US Food and Drug Administration (FDA)-approved nontoxic food dye [53,54], our data argues for its evaluation in a human NTG-induced migraine model.

\begin{abstract}
Abbreviations
ANOVA: Analysis of variance; ATP: Adenosine triphosphate; BBG: Brilliant Blue G; C1-2: Upper cervical spinal cord; CGRP: Calcitonin gene related peptide; CNS: Central nervous system; DNA: Deoxyribonucleic acid; FDA: Food and Drug Administration; ITHT: Increasing temperature hot plate test; IHC: Immunohistochemistry; IL-1 $\beta$ : Interleukin-1 beta; NGF: Nerve growth factor; NO: Nitric oxide; NTG: Nitroglycerin; P2X7: P2X7 receptor; PCR: Polymerase chain reaction; PWT: Paw withdrawal threshold; SEM: Standard error of the mean; TNC: Trigeminal nucleus caudalis; TNF-a: Tumor necrosis factor-a.
\end{abstract}

\section{Competing interests}

The authors declare that they have no competing interests.

\section{Authors' contributions}

FG carried out all experiments, analyzed data, performed statistical analyses and drafted the manuscript. BS designed and supervised the study, and finalized the paper. Both authors read and approved the final manuscript.

\footnotetext{
Acknowledgements

The authors are grateful to Ágnes Kittel and Rómeó D. Andó in their help in setting up the experimental procedures, for Ed Beamer for editing the manuscript and for Bence Koványi for technical assistance.

This work was supported by the Hungarian Research and Development Fund [grant number NN107234]; Hungarian Office of Science and Technology [grant number TÉT_10-1-2011-0050] and the European Research Council [grant number 294313-SERRACO].
}

\section{Author details}

'Laboratory of Molecular Pharmacology, Institute of Experimental Medicine, Hungarian Academy of Sciences, H-1083, Budapest, Szigony u. 43, Hungary. ${ }^{2}$ János Szentágothai School of Neurosciences, Semmelweis University School of Ph.D Studies, Budapest, Hungary.
Received: 30 January 2014 Accepted: 15 April 2014

Published: 1 May 2014

\section{References}

1. Stovner L, Hagen K, Jensen R, Katsarava Z, Lipton R, Scher A, Steiner T, Zwart JA (2007) The global burden of headache: a documentation of headache prevalence and disability worldwide. Cephalalgia 27(3):193-210

2. Natoli JL, Manack A, Dean B, Butler Q, Turkel CC, Stovner L, Lipton RB (2010) Global prevalence of chronic migraine: a systematic review. Cephalalgia 30 (5):599-609

3. Olesen J, Ashina M (2011) Emerging migraine treatments and drug targets. Trends Pharmacol Sci 32(6):352-359

4. Burstein R, Yarnitsky D, Goor-Aryeh I, Ransil BJ, Bajwa ZH (2000) An association between migraine and cutaneous allodynia. Ann Neurol 47(5):614-624

5. Bigal ME, Ashina S, Burstein R, Reed ML, Buse D, Serrano D, Lipton RB, Group A (2008) Prevalence and characteristics of allodynia in headache sufferers: a population study. Neurology 70(17):1525-1533

6. Gupta S, Villalon CM (2010) The relevance of preclinical research models for the development of antimigraine drugs: focus on 5-HT(1B/1D) and CGRP receptors. Pharmacol Ther 128(1):170-190

7. Iversen HK, Olesen J, Tfelt-Hansen P (1989) Intravenous nitroglycerin as an experimental model of vascular headache. Basic characteristics. Pain 38 (1):17-24

8. Sicuteri F, Del Bene E, Poggioni M, Bonazzi A (1987) Unmasking latent dysnociception in healthy subjects. Headache 27(4):180-185

9. Sances G, Tassorelli C, Pucci E, Ghiotto N, Sandrini G, Nappi G (2004) Reliability of the nitroglycerin provocative test in the diagnosis of neurovascular headaches. Cephalalgia 24(2):110-119

10. Bahra A, Matharu MS, Buchel C, Frackowiak RS, Goadsby PJ (2001) Brainstem activation specific to migraine headache. Lancet 357(9261):1016-1017

11. Tvedskov JF, Thomsen LL, Iversen HK, Gibson A, Wiliams P, Olesen J (2004) The prophylactic effect of valproate on glyceryltrinitrate induced migraine. Cephalalgia 24(7):576-585

12. Tvedskov JF, Thomsen LL, Thomsen LL, Iversen HK, Williams P, Gibson A, Jenkins K, Peck R, Olesen J (2004) The effect of propranolol on glyceryltrinitrate-induced headache and arterial response. Cephalalgia 24 (12):1076-1087

13. de Tommaso M, Libro G, Guido M, Difruscolo O, Losito L, Sardaro M, Cerbo R (2004) Nitroglycerin induces migraine headache and central sensitization phenomena in patients with migraine without aura: a study of laser evoked potentials. Neurosci Lett 363(3):272-275

14. Bates EA, Nikai T, Brennan KC, Fu YH, Charles AC, Basbaum Al, Ptacek LJ, Ahn AH (2010) Sumatriptan alleviates nitroglycerin-induced mechanical and thermal allodynia in mice. Cephalalgia 30(2):170-178

15. Tassorelli C, Joseph SA (1995) Systemic nitroglycerin induces Fos immunoreactivity in brainstem and forebrain structures of the rat. Brain Res 682(1-2):167-181

16. Lambert GA, Donaldson C, Boers PM, Zagami AS (2000) Activation of trigeminovascular neurons by glyceryl trinitrate. Brain Res 887(1):203-210

17. Sixt ML, Messlinger K, Fischer MJ (2009) Calcitonin gene-related peptide receptor antagonist olcegepant acts in the spinal trigeminal nucleus. Brain 132(Pt 11):3134-3141

18. Burnstock $G$ (1981) Pathophysiology of migraine: a new hypothesis. Lancet 1(8235):1397-1399

19. Ambalavanar R, Moritani M, Dessem D (2005) Trigeminal P2X3 receptor expression differs from dorsal root ganglion and is modulated by deep tissue inflammation. Pain 117(3):280-291

20. Fabbretti E, D'Arco M, Fabbro A, Simonetti M, Nistri A, Giniatullin R (2006) Delayed upregulation of ATP P2X3 receptors of trigeminal sensory neurons by calcitonin gene-related peptide. J Neurosci 26(23):6163-6171

21. Fumagalli M, Ceruti S, Verderio C, Abbracchio M (2006) ATP as a neurotransmitter of pain in migraine: a functional role for $\mathrm{P} 2 \mathrm{Y}$ receptors in primary cultures from mouse trigeminal sensory ganglia. Purinergic signalling 2(1):120-121

22. D'Arco M, Giniatullin R, Simonetti M, Fabbro A, Nair A, Nistri A, Fabbretti E (2007) Neutralization of nerve growth factor induces plasticity of ATP-sensitive P2X3 receptors of nociceptive trigeminal ganglion neurons. J Neurosci 27 (31):8190-8201

23. Simonetti M, Giniatullin R, Fabbretti E (2008) Mechanisms mediating the enhanced gene transcription of P2X3 receptor by calcitonin gene-related peptide in trigeminal sensory neurons. J Biol Chem 283(27):18743-18752 
24. Ceruti S, Villa G, Fumagalli M, Colombo L, Magni G, Zanardelli M, Fabbretti E, Verderio C, van den Maagdenberg AM, Nistri A, Abbracchio MP (2011) Calcitonin gene-related peptide-mediated enhancement of purinergic neuron/glia communication by the algogenic factor bradykinin in mouse trigeminal ganglia from wild-type and R192Q Cav2.1 Knock-in mice: implications for basic mechanisms of migraine pain. J Neurosci 31(10):3638-3649

25. Heinrich A, Ando RD, Turi G, Rozsa B, Sperlagh B (2012) K+ depolarization evokes ATP, adenosine and glutamate release from glia in rat hippocampus: a microelectrode biosensor study. Br J Pharmacol 167(5):1003-1020

26. Schock SC, Munyao N, Yakubchyk Y, Sabourin LA, Hakim AM, Ventureyra EC, Thompson CS (2007) Cortical spreading depression releases ATP into the extracellular space and purinergic receptor activation contributes to the induction of ischemic tolerance. Brain Res 1168:129-138

27. D'Amico M, Samengo I, Navarra P, Taglialatela M, Martire M (2010) AMPAand P2X7-receptor-mediated facilitation of [3H]D-aspartate release from nerve terminals isolated from the rat caudal brainstem. Neurochem Int 57 (6):623-628

28. Able SL, Fish RL, Bye H, Booth L, Logan YR, Nathaniel C, Hayter P, Katugampola SD (2011) Receptor localization, native tissue binding and ex vivo occupancy for centrally penetrant P2X7 antagonists in the rat. Br J Pharmacol 162(2):405-414

29. Magni G, Ceruti S (2013) P2Y purinergic receptors: new targets for analgesic and antimigraine drugs. Biochem Pharmacol 85(4):466-477

30. Chessell IP, Hatcher JP, Bountra C, Michel AD, Hughes JP, Green P, Egerton J, Murfin M, Richardson J, Peck WL, Grahames CB, Casula MA, Yiangou Y, Birch R, Anand P, Buell GN (2005) Disruption of the P2X7 purinoceptor gene abolishes chronic inflammatory and neuropathic pain. Pain 114(3):386-396

31. Ando RD, Sperlagh B (2013) The role of glutamate release mediated by extrasynaptic P2X7 receptors in animal models of neuropathic pain. Brain Res Bull 93:80-85

32. Ando RD, Mehesz B, Gyires K, Illes P, Sperlagh B (2010) A comparative analysis of the activity of ligands acting at P2X and P2Y receptor subtypes in models of neuropathic, acute and inflammatory pain. Br J Pharmacol 159 (5):1106-1117

33. Honore P, Donnelly-Roberts D, Namovic MT, Hsieh G, Zhu CZ, Mikusa JP, Hernandez G, Zhong C, Gauvin DM, Chandran P, Harris R, Medrano AP, Carroll W, Marsh K, Sullivan JP, Faltynek CR, Jarvis MF (2006) A-740003 [N-(1-\{[(cyanoimino)(5-quinolinylamino) methyl] amino\}-2,2-dimethylpropyl)-2-(3,4-dimethoxyphenyl) acetamide], a novel and selective P2X7 receptor antagonist, dose-dependently reduces neuropathic pain in the rat. J Pharmacol Exp Ther 319(3):1376-1385

34. Chu $Y X$, Zhang $Y$, Zhang $Y Q$, Zhao ZQ (2010) Involvement of microglial $\mathrm{P} 2 \mathrm{X} 7$ receptors and downstream signaling pathways in long-term potentiation of spinal nociceptive responses. Brain Behav Immun 24(7):1176-1189

35. McGaraughty S, Chu KL, Namovic MT, Donnelly-Roberts DL, Harris RR, Zhang XF, Shieh CC, Wismer CT, Zhu CZ, Gauvin DM, Fabiyi AC, Honore P, Gregg RJ, Kort ME, Nelson DW, Carroll WA, Marsh K, Faltynek CR, Jarvis MF (2007) P2X7-related modulation of pathological nociception in rats. Neuroscience 146(4):1817-1828

36. Sorge RE, Trang T, Dorfman R, Smith SB, Beggs S, Ritchie J, Austin JS, Zaykin DV, Vander Meulen $\mathrm{H}$, Costigan M, Herbert TA, Yarkoni-Abitbul M, Tichauer D, Livneh J, Gershon E, Zheng M, Tan K, John SL, Slade GD, Jordan J, Woolf CJ, Peltz G, Maixner W, Diatchenko L, Seltzer Z, Salter MW, Mogil JS (2012) Genetically determined P2X7 receptor pore formation regulates variability in chronic pain sensitivity. Nat Med 18(4):595-599

37. Solle M, Labasi J, Perregaux DG, Stam E, Petrushova N, Koller BH, Griffiths RJ, Gabel CA (2001) Altered cytokine production in mice lacking P2X(7) receptors. J Biol Chem 276(1):125-132

38. Diaz-Hernandez M, Diez-Zaera M, Sanchez-Nogueiro J, Gomez-Villafuertes R, Canals JM, Alberch J, Miras-Portugal MT, Lucas JJ (2009) Altered P2X7receptor level and function in mouse models of Huntington's disease and therapeutic efficacy of antagonist administration. FASEB J 23(6):1893-1906

39. Csolle C, Ando RD, Kittel A, Goloncser F, Baranyi M, Soproni K, Zelena D, Haller J, Nemeth T, Mocsai A, Sperlagh B (2013) The absence of P2X7 receptors ( $\mathrm{P} 2 \mathrm{r} \times 7)$ on non-haematopoietic cells leads to selective alteration in mood-related behaviour with dysregulated gene expression and stress reactivity in mice. Int J Neuropsychopharmacol 16(1):213-233

40. Sokolowska M, Bednarski M, Kwiecien I, Filipek B, Wlodek L (2004) Bioactivation of nitroglycerin to nitric oxide (NO) and S-nitrosothiols in the rat liver and evaluation of the coexisting hypotensive effect. Fundam Clin Pharmacol 18(4):449-456
41. Almasi R, Petho G, Bolcskei K, Szolcsanyi J (2003) Effect of resiniferatoxin on the noxious heat threshold temperature in the rat: a novel heat allodynia model sensitive to analgesics. Br J Pharmacol 139(1):49-58

42. Hracsko Z, Baranyi M, Csolle C, Goloncser F, Madarasz E, Kittel A, Sperlagh B (2011) Lack of neuroprotection in the absence of P2X7 receptors in toxininduced animal models of Parkinson's disease. Mol Neurodegener 6:28

43. Jo S, Bean BP (2011) Inhibition of neuronal voltage-gated sodium channels by brilliant blue G. Mol Pharmacol 80(2):247-257

44. Diaz-Hernandez Jl, Gomez-Villafuertes R, Leon-Otegui M, Hontecillas-Prieto L, Del Puerto A, Trejo JL, Lucas JJ, Garrido JJ, Gualix J, Miras-Portugal MT, Diaz-Hernandez M (2012) In vivo P2X7 inhibition reduces amyloid plaques in Alzheimer's disease through GSK3beta and secretases. Neurobiol Aging 33 (8):1816-1828

45. Jiang LH, Mackenzie AB, North RA, Surprenant A (2000) Brilliant Blue G selectively blocks ATP-gated rat P2X(7) receptors. Mol Pharmacol 58(1):82-88

46. Collier HO, James GW, Schneider C (1966) Antagonism by aspirin and fenamates of bronchoconstriction and nociception induced by adenosine5'-triphosphate. Nature 212(5060):411-412

47. Sperlagh B, Vizi ES, Wirkner K, Illes P (2006) P2X(7) receptors in the nervous system. Prog Neurobiol 78(6):327-346

48. Zhang X, Chen Y, Wang C, Huang LY (2007) Neuronal somatic ATP release triggers neuron-satellite glial cell communication in dorsal root ganglia. Proc Natl Acad Sci U S A 104(23):9864-9869

49. Teixeira JM, Oliveira MC, Nociti FH Jr, Clemente-Napimoga JT, Pelegrini-da-Silva A, Parada CA, Tambeli CH (2010) Involvement of temporomandibular joint P2X3 and $\mathrm{P} 2 \mathrm{X} 2 / 3$ receptors in carrageenan-induced inflammatory hyperalgesia in rats. Eur J Pharmacol 645(1-3):79-85

50. Nair A, Simonetti M, Birsa N, Ferrari MD, van den Maagdenberg AM, Giniatullin R, Nistri A, Fabbretti E (2010) Familial hemiplegic migraine Ca(v) 2.1 channel mutation $\mathrm{R} 192 \mathrm{Q}$ enhances ATP-gated $\mathrm{P} 2 \mathrm{X} 3$ receptor activity of mouse sensory ganglion neurons mediating trigeminal pain. Mol Pain 6:48

51. Akerman S, Holland PR, Goadsby PJ (2011) Diencephalic and brainstem mechanisms in migraine. Nat Rev Neurosci 12(10):570-584

52. Csolle C, Sperlagh B (2010) Peripheral origin of IL-1beta production in the rodent hippocampus under in vivo systemic bacterial lipopolysaccharide (LPS) challenge and its regulation by P2X(7) receptors. J Neuroimmunol 219 $(1-2): 38-46$

53. Remy M, Thaler S, Schumann RG, May CA, Fiedorowicz M, Schuettauf F, Gruterich M, Priglinger SG, Nentwich MM, Kampik A, Haritoglou C (2008) An in vivo evaluation of Brilliant Blue $\mathrm{G}$ in animals and humans. $\mathrm{Br}$ J Ophthalmol 92(8):1142-1147

54. Wong HE, Qi W, Choi HM, Fernandez EJ, Kwon I (2011) A safe, blood-brain barrier permeable triphenylmethane dye inhibits amyloid-beta neurotoxicity by generating nontoxic aggregates. ACS Chem Neurosci 2(11):645-657

\section{doi:10.1186/1129-2377-15-24}

Cite this article as: Gölöncsér and Sperlágh: Effect of genetic deletion and pharmacological antagonism of $\mathrm{P} 2 \mathrm{X} 7$ receptors in a mouse animal model of migraine. The Journal of Headache and Pain 2014 15:24.

\section{Submit your manuscript to a SpringerOpen ${ }^{\odot}$ journal and benefit from:}

- Convenient online submission

Rigorous peer review

- Immediate publication on acceptance

- Open access: articles freely available online

- High visibility within the field

- Retaining the copyright to your article

Submit your next manuscript at springeropen.com 